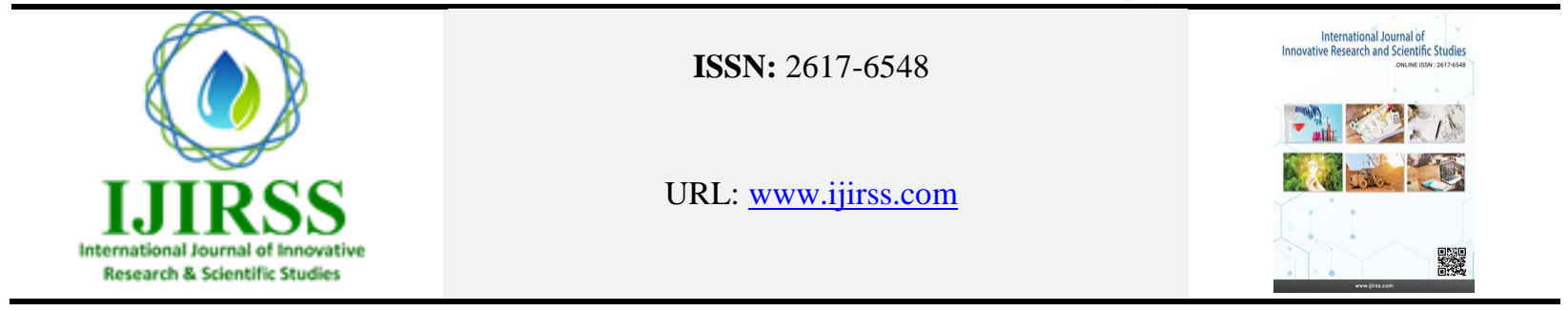

\title{
Comparative Analysis of Economic Aspects of Concentrated Solar Power Versus Photovoltaic in Afghanistan - Case study: Kang district, Nimruz
}

\author{
Ali Ahmad Amiri \\ ${ }^{I}$ Department of Rural Rehabilitation and Development, Citizens' Charter National Priority Program, Kang-Nimruz, Afghanistan
}

(Amiri163@yahoo.com)

\begin{abstract}
This paper analyzes the impacts of whole solar energy technologies on the economic situation of Afghanistan. Details and positive effects of solar mini-grids which are implemented through the Citizens' Charter National Priority Program CCNPP in the rural areas of Afghanistan are given as samples of solar energy projects in Afghanistan. The result of this analysis then compared with the fossil fuel electricity that people use in the rural areas of Afghanistan based on the economic effects. The Levelized Cost of Energy (LCOE) for electricity generated through the diesel generator is estimated to be $29 \notin / \mathrm{kWh}$, which is 3.16 times higher than the cost of electricity produced via photovoltaic (PV) in $9.17 \phi / \mathrm{kWh}$. The potential for solar thermal as a recently boomed technology in the world is also studied with regard to the climate, economy, and security situation of Afghanistan. The country with 300 sunny days in a year has $1900-2000 \mathrm{kWh} / \mathrm{m} 2$ potential of producing electricity through the Concentrated Solar Power (CSP) technology. Using Multi-Criteria Decision Analysis (MCDA) the Parabolic Trough Collector (PTC) is selected as an optimal type of CSP in Afghanistan and a 3.5 MW PTC power plant is simulated via the System Advisor Model (SAM) software. The result of this simulation shows that this novel technology in Afghanistan needs more time and efforts to set as a secure approach of energy.
\end{abstract}

Keywords: Solar Photovoltaic, Concentrated Solar Power, Multi-Criteria Decision Analysis, System Advisor Model.

DOI: $10.53894 /$ ijirss.v4i2.64

Funding: This study received no specific financial support.

History: Received: 8 January 2020/Revised: 10 February 2021/Accepted: 16 March 2021/Published: 30 March 2021

Licensed: This work is licensed under a Creative Commons Attribution 4.0 License $(\mathrm{cc}) \mathrm{EY}$

Competing Interests: The author declares that there are no conflicts of interests regarding the publication of this paper.

Transparency: The author confirms that the manuscript is an honest, accurate, and transparent account of the study was reported; that no vital features of the study have been omitted; and that any discrepancies from the study as planned have been explained.

Ethical: This study follows all ethical practices during writing.

\section{Introduction}

The electricity shortfall is concentrated mostly in southern Asia and Africa, and particularly in rural populations in these regions: 8 out of 10 who lack electricity are in rural areas of the developing world [1]. In Afghanistan over $70 \%$ of people live in rural areas and $61 \%$ of all population derive their income from agriculture [2]. However, recently, most people have left their farms and agricultural occupations due to the insecurity issues and high cost of energy. That is why energy could play a key precondition role in developing the economy of the country. Lack of electricity in Afghanistan is the major reason for a bunch of problems including, poverty, lack of awareness, sanitation difficulties, and even insecurity. However, Afghanistan with over 300 sunny days is a great source of solar energy production. Nevertheless, the country has never experienced any enrichment period of energy production for the entire population. Afghanistan pays annually 
\$280 million to import 670 MW of electricity from neighboring countries, but despite the huge expense of imported power, only 35 percent of Afghans have access to electricity through grids [3]. The national grid supply largely consists of imports from Iran, Uzbekistan, Tajikistan, Turkmenistan and somewhat supplemented by electricity from domestic hydropower plants (HPPs) [4]. The rate of generation, consumption and imported electricity is also obvious from Figure 1, which shows the largest part of electricity of country is imported.

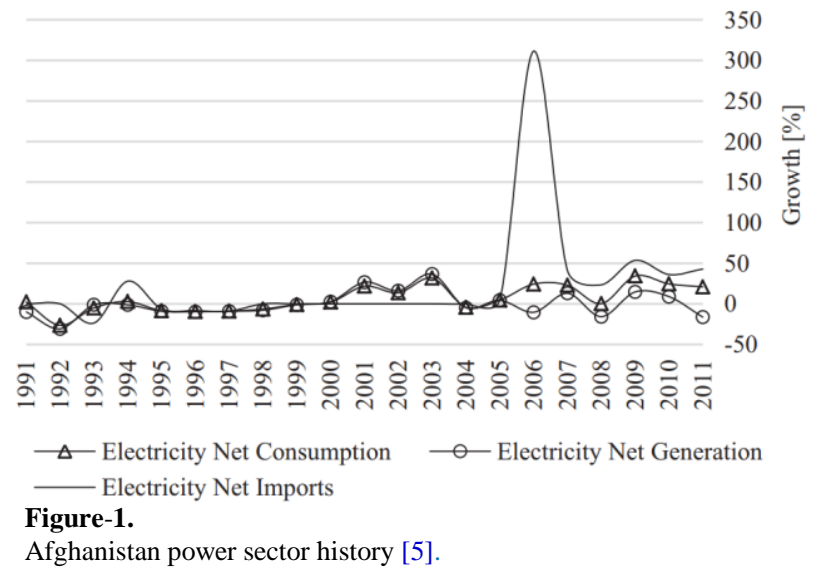

As national grids are not available in every spot of the country and conventional fossil fuel energy sources are diminishing, renewable energy, and in particular solar energy, is becoming a valid alternative to traditional energy since it provides significant environmental benefits. Moreover, solar energy is considered clean, free, and inexhaustible [6]. The concentrated solar power (CSP) technology as another form of solar energy is a future-oriented and promising renewable energy technology that in the last years attracted more and more interest from energy utilities around the world. The CSP technology captures solar radiation and transforms it into thermal energy that generates electricity through steam turbines. The future of CSP technology seems to be very promising, but, due to its high cost, it is still ambiguous if this is a possible or fair solution for electrification of a developing country like Afghanistan. The objective of this study is to compare and analyze the potential for the implementation of photovoltaic (PV) and CSP electricity generation in rural areas of Afghanistan. The results of this study can help to determine if the CSP could be a suitable approach for the electrification of Afghanistan. It can also facilitate decision-making regarding the implementation of any PV or CSP project in rural areas of the country and ensure the private and public sectors for investing in any of these two fields of renewable energy. The methodology of this study is developed based on the solar mini-grid projects implemented in the Kang district by the Citizens' Charter National Priority Program (CCNPP) and simulation of a $3.5 \mathrm{MW}$ concentrated solar power plant via SAM software.

\subsection{Description of implemented photovoltaic systems and case study}

Kang district in the Nimruz province is located in the southwestern part of the country, this district has 62 local community development councils (CDCs) and an area of 1250 sq. km. The recent survey was done via the Citizens' Charter National Priority Program (CCNPP) in August 2020, declares that the number of households in this area are 2116 and an absolute majority of residents are involved in cultivation.

The distance between the Kang and the nearest national grid is $25 \mathrm{~km}$, so, extending the electric grid costs a lot of money. On the other hand, electricity imported from Iran is only for the Zaranj population and cannot be supplied for the Kang people. Apart from all advantages and disadvantages of solar energy, this is the most suitable solution to the lack of electricity in rural areas of Afghanistan that is examined and going to be continued in the future. Among these 62 CDCs of Kang district, 31 of them have been supplied electricity via PV-based mini-grid projects through the World Bank's budget. The projects are designed for six hours in the form of community solar PVs, with a whole power of $146 \mathrm{~kW}$ for 1200 households. The electricity generated via these mini-grids is used for lightening, charging mobiles, and using Light Emitting Diode (LED) televisions. The smallest project is designed in this city is for 25 households, the specifications shown below are for projects implemented in the Kang (Table 1).

Table-1.

Specifications of solar mini-grid projects in Kang.

\begin{tabular}{c|c|c|c|c}
\hline Solar panel & Battery & Invertor & Fuse & Cable area thickness (mm) \\
\hline $260 \mathrm{~W}$, Mono/poly (Crystalline) & $220 \mathrm{Ah}, 12 \mathrm{~V}$ & Single/three phase & $0.5 \mathrm{Ah}$ & $25 \mathrm{~mm}^{2}$ \\
\hline
\end{tabular}

However, the poly-crystalline solar panels occupied mostly the markets of Afghanistan due to their low-cost, still, the mono-crystalline solar panels are more suitable and effective, especially for the Nimruz region. This is because usually the Nimruz weather is dusty and block the sunlight by covering the surface of solar panels with dust particles, thus, the monocrystalline solar panels with high efficiency of $21 \%$ are more suitable for this province. Additionally, the high temperature of this region especially in the summer which is reported $52{ }^{\circ} \mathrm{C}$, caused to use sealed gel batteries for these projects. These mini-grid projects as an introduction to solar energy for people of this area, lead these people to use other solar equipment 
as well, which has decreased the Levelized cost of energy in the rural spots from $29 \phi / \mathrm{kWh}$ produced with diesel generators to $9.17 \phi / \mathrm{kWh}$ solar energy.

$$
L C O E=\frac{\text { Net Present Value of total cost over life time }}{\text { Net Present Value of electrical energy produced over life time }}
$$

Additionally, the environmental effects of fossil fuel extremely reduced as well; 1 liter of diesel which generates $2.5 \mathrm{~kW}$ electricity, on the other hand, produces 2640 grams of $\mathrm{CO}_{2}$ [7]. However, the $\mathrm{CO}_{2}$ emission in the PV systems is equal to zero.

\subsection{Potential analyses of photovoltaic in Afghanistan}

Afghanistan has many high potential sources of renewable energies such as wind, hydro, biomass, geothermal, and solar. The solar source has the highest capacity of generating energy in the country as shown in Figure 2 annually $222 \mathrm{GW}$ of energy can be produced through solar radiation over the geographical area of Afghanistan. Additionally, Figure 3 shows the photovoltaic power potential of Afghanistan. In the case study of Kang district, a $1 \mathrm{~kW}$-peak grid-connected solar power plant has the capability of production $4.8-5.2 \mathrm{~kW}$ over the daytime. Hence, Kang is a suitable site for the PVbased mini-grid projects with a high potential to supply the demand for electricity of this area.

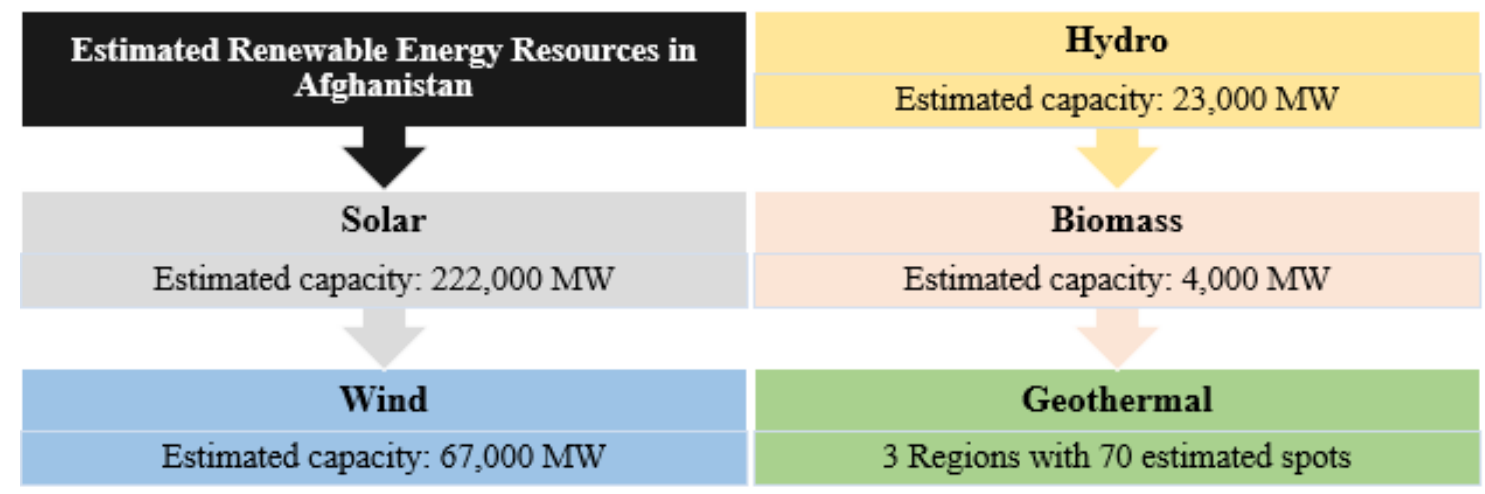

Figure-2.

Estimated renewable energy potential in Afghanistan [8]

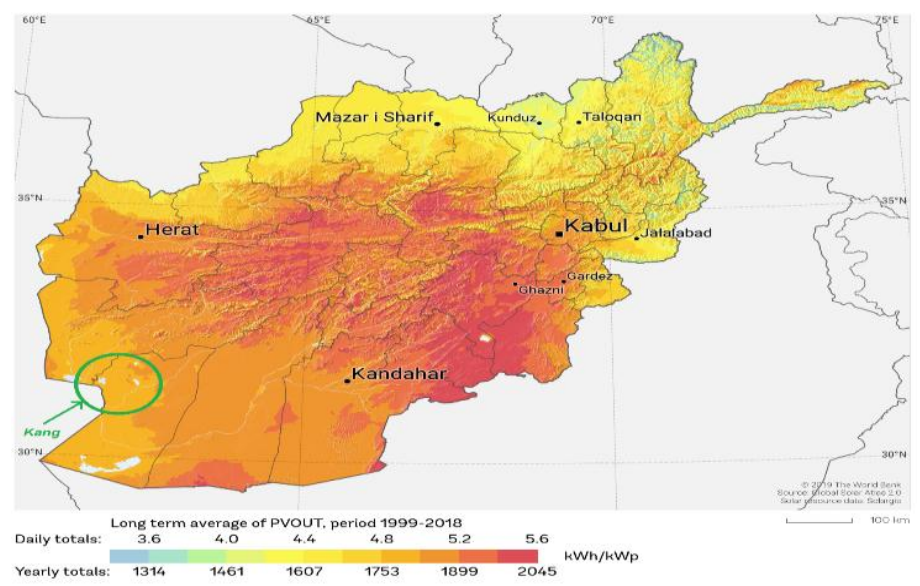

Figure-3.

Direct normal irradiation (DNI) of Afghanistan [9].

\section{Types of commercialized CSP plants}

All concentrated solar power (CSP) technologies use mirrors to reflect the concentrated sun's light onto receivers. The receivers convert the light into heat which is used to drive steam turbines, gas turbines, or Stirling engines to create electricity through power generators. Thermal energy storage (TES) shown in Figure 4 is a novel and techno-economic replacement of batteries in solar energy technology which has a high capacity of storing a high amount of heat for up to 10 hours, to produce electricity during the lack of sun's light. 


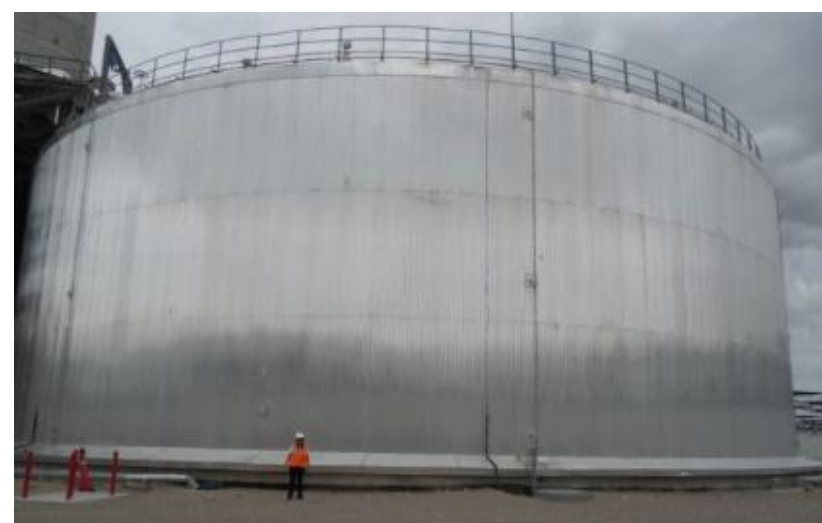

\section{Figure-4.}

The (TES) tank at the Crescent Dunes in Nevada holds molten salt at $565^{\circ} \mathrm{C}[10]$.

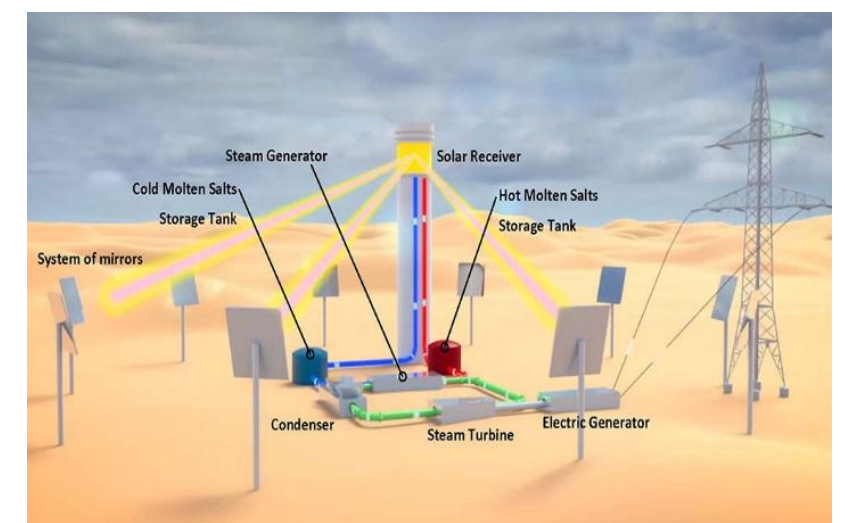

Figure-5.

The SPT power plant [11].

Four optical types of CSP technology developed so far, can be identified as bellow:

- Parabolic Trough Collector (PTC)

- Linear Fresnel Reflector (LFR)

- Solar power tower (SPT)

- Parabolic Dish Collector (PDC)

The SPT shown in Figure 5 and PDC is point-focused types of CSP collectors, while the PTC and LFR showed in Figures 7 and 8 respectively are line focus types of collectors. The point focused systems have relatively low-efficiency advantages compared to parabolic trough technologies [12].

\subsection{Parabolic Trough Collector}

The parabolic trough systems use parabolically curved mirrors to reflect the sun's light onto a receiver pipe located about a meter above the reflector and arranged in a north-south direction Figure 6. The main components of a PTC power plant as shown in Figure 7 are including reflectors, receivers, storage tanks, steam condensers, and turbines. The temperature for heat transfer fluid (HTF) flowing through the receiver tubes range from 100 to $400{ }^{\circ} \mathrm{C}$, suitable for a variety of applications [13]. According to the range of the operating temperature, PTC can be divided into two categories, one is in the temperature range of $300-400{ }^{\circ} \mathrm{C}$ (mainly used to generate power) and another is in the temperature range of 100-250 ${ }^{\circ} \mathrm{C}$ (for the industrial process heating) [14]. The HTF in use for the CSP plant with PTC system is mostly the thermal oil, water, pressurized air, and molten salt but all of them have relatively low thermal conductivity. Therefore, an effective method to improve the effectiveness of thermal conductivity is using Nano-sized particles (1-100 nm) suspended in the heat transfer fluid [15]. These Nano-sized particles are typically $\mathrm{Al}_{2} \mathrm{O}_{3}, \mathrm{ZnO}, \mathrm{Cu}, \mathrm{Au}, \mathrm{TiO}_{2}, \mathrm{Al}, \mathrm{Fe}_{2} \mathrm{O}_{3}, \mathrm{CuO}$, and $\mathrm{SiO}_{2}$ [16]. Another vital part of PTC is the TES, which is used for large-scale concentrated solar thermal power plants. It is generally provided to allow electricity production at night and overcast days [17]. The parabolic trough power plants are suitable for power generation capacities in the range of 10-200 MW [18]. The PTC has the highest rate of implementation in the world, in 2018, 90\% of the CSP in commercial operation is trough [10]. Yet there are efforts to develop the future generation of CSP plants with PTC systems through increasing the operating temperature. Which will increase the demand for this technology even more. In order to achieve a higher operating temperature, the next generation of HTF for PTC systems need to be developed, plus the material of metal tube for HTF needs improvement. Inexpensive metal materials with superb thermos-mechanical properties would be the most possible method of solving these issues [19].

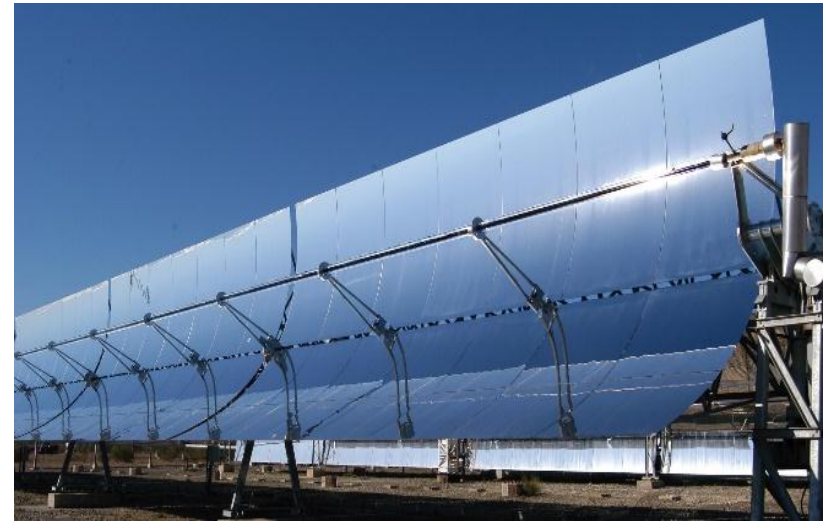

Figure-6.

Parabolic-trough solar collector at Plataforma Solar de Almería in Spain [20].

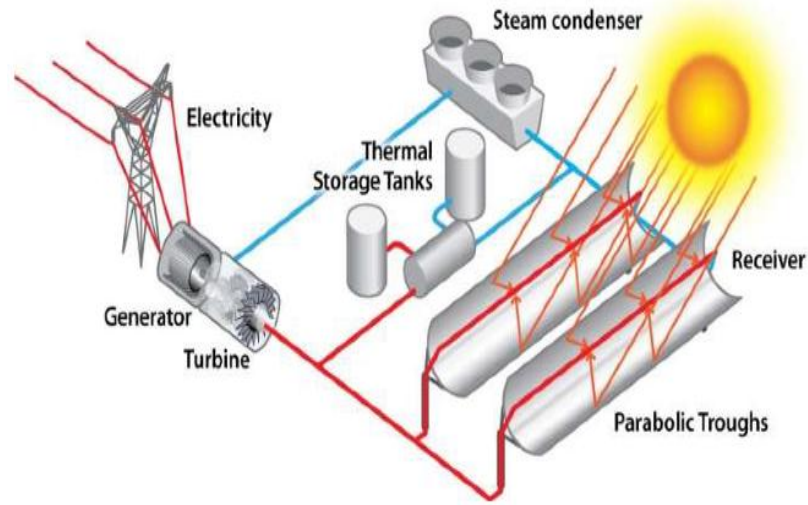

Figure-7.

Parabolic-trough solar collector [21]. 


\subsection{Linear fresnel reflector (LFR)}

Similar to PTC systems, the LFR systems also consist of numerous collectors in parallel rows, placed close to the ground that makes the mechanical difficulties due to wind load to be low and land utilization is low as well [22]. These reflectors are oriented in a north-south direction, following the path of the sun to reflect the sunlight towards the HTF tubes while the receiver tube itself is constant Figure 8. The HTF in the receiver tubes is the usual choice as PTCs, however, the thermal oil with $400{ }^{\circ} \mathrm{C}$ and molten salt with $600{ }^{\circ} \mathrm{C}$ can also be used. In contrast to its competitive technology PTCs, Linear Fresnel Reflectors have the advantages of easy production and lower construction, moreover, the segmented reflectors of LFR made it possible to have more sunlight concentration without great land utilization. The LFR has a lightweight supporting system which makes its cost to be lower than other CSPs technology. The concentration ratios for LFR are in the same ranges of PTC, generally, 10 up to 50 and the operating temperatures of both technologies can be up to $400-500{ }^{\circ} \mathrm{C}[23]$.

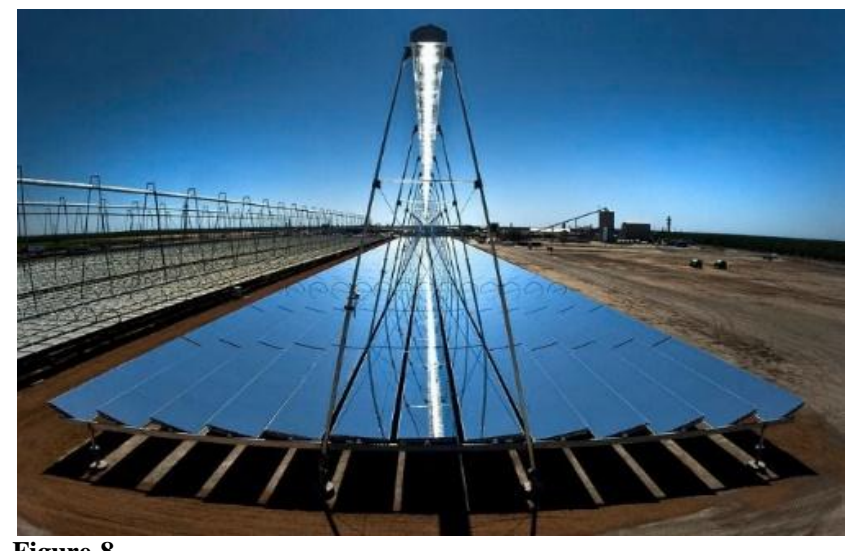

\section{Figure-8.}

Compact Linear Fresnel Reflector a photograph by Us Department of Energy [24].

\subsection{Solar power tower (SPT)}

Power tower systems use sun-tracking mirrors called heliostats, which are flat flare glasses as shown in Figure 9, compared to parabolic trough these mirrors are also less expensive. These glasses reflect the sunlight onto the receiver placed atop a fixed tower Figure 10. The HTF in the receiver can be increased up to $1000-1200{ }^{\circ} \mathrm{C}$ depending on the properties of the material and HTF used [25]. The generated steam of HTF, in turn, used to power up a turbine to generate electricity.

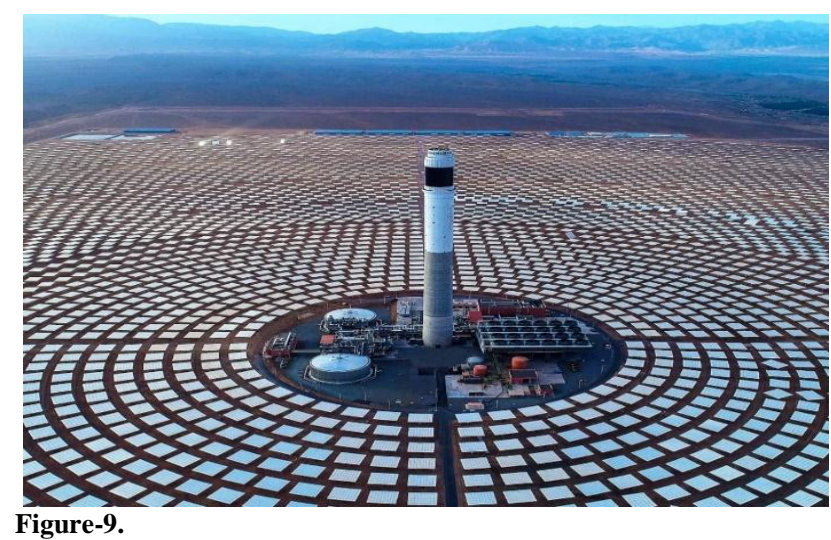

The 580 MW Noor Ouarzazate Solar power station [26].

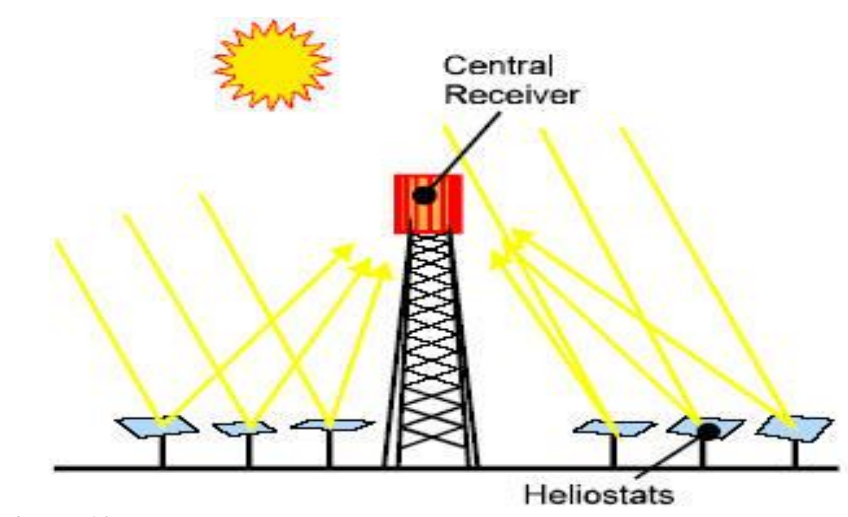

Figure-10.

The process of sunlight reflection [27].

The HTF used in the SPT system is different, some commercial tower plants now in operation using direct steam generation (DSG), and others use different fluids, including molten salts, which can be stored thermally in the hot tank for a longer time to be used after sunset or on cloudy days [28].

\subsection{Parabolic dish collector (PDC)}

Parabolic dish collectors (PDC) are two-axis solar tracking systems that concentrate the sunrays toward the thermal receiver located on the focal point of the dish [29]. The receiver on the dish is usually a Stirling engine or a micro-turbine, which is the main component of this system. Dish-Stirling systems have demonstrated the highest efficiency of any solar power generation system by converting nearly $30 \%$ of direct-normal incident solar radiation into electricity after accounting for parasitic power losses [30]. The PDCs' size is limited by material constraints, and the largest one of them is $10 \mathrm{~m}$ in diameter that generates $25 \mathrm{KW}$ electricity [31]. The HTF in this type of CSP system is not used and the PDCs are rarely connected together, so, each dish produces electricity separately. Therefore, the dishes have a low capacity for 
electricity production. Typically, PDCs are recommended for lower generation capacity between 0.1-0.4 MW so, it is expensive than other types of CSPs $[18,30]$.

\subsection{Potential of CSP technology in Afghanistan}

Site selection as the first step has a significant impact on the cost, efficiency, and entire life of CSP plants. Multicriteria observance like availability of flat land, water resource, electricity network, and road expected to be considered for the relevant sites [32]. Based on the site selection requirements, the Direct Normal Irradiation (DNI) for the site of a CSP plant should be over $1800 \mathrm{kWh} / \mathrm{m}^{2} /$ year $\left(5.2 \mathrm{kWh} / \mathrm{m}^{2} /\right.$ day $)$ [33]. Considering all these points, not only the land is available enough for whatever size of CSP project in Afghanistan, but also the DNI is capable of operating all kinds of CSP projects as shown in Figure 11; the DNI in the Kang district is $1900-2000 \mathrm{kWh} / \mathrm{m}^{2} /$ year. Moreover, the wind speed of a suitable site for a CSP power plant should be less than $15.64 \mathrm{~m} / \mathrm{s}$, the highest wind speed in the Kang is $6.75 \mathrm{~m} / \mathrm{s}$ which cannot cause structural damages to the collectors $[34,35]$. In addition, good facilities of transportation and water resources are other vital criteria for a PTC power plant, to be available enough in the area.

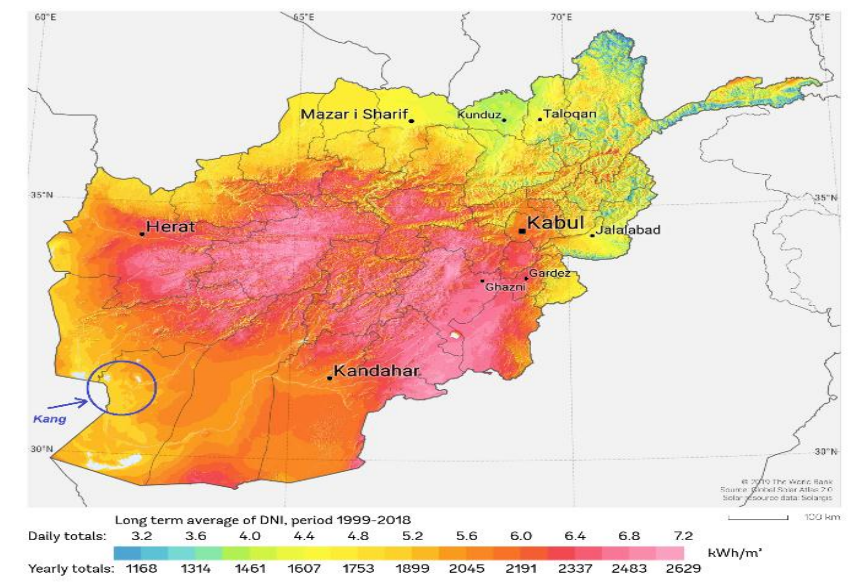

Figure-11.

Annual DNI potential of Kang district is $1900 \mathrm{kWh} / \mathrm{m}^{2}$ [9].

2.6. Using multi-criteria decision analysis (MCDA) for selection of optimal CSP Type

Based on the economic situation of people in Afghanistan four factors are selected as criteria of the MCDA process, including cost, durability, security, and site, for selecting the most suitable type of a CSP for the Kang district. The analysis resulted in the below chart (Figure 12).

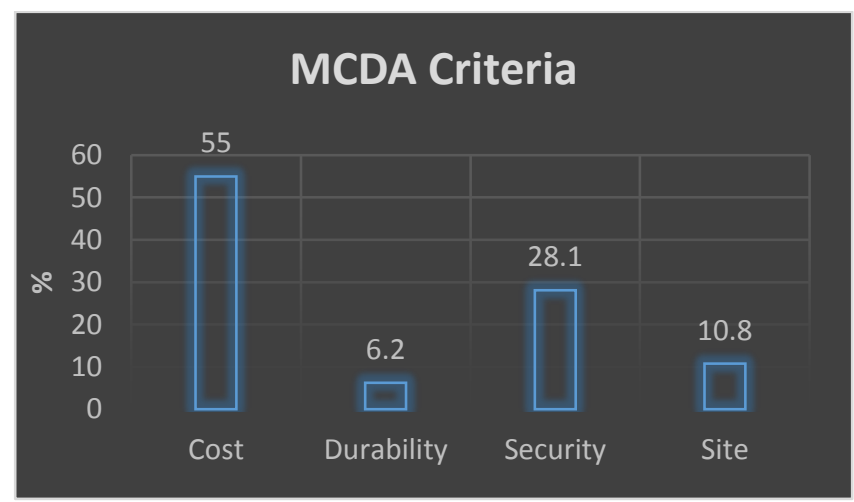

Figure-12.

Percentage of MCDA factors for selection of optimal type of CSP.

Figure 12 shows the cost with the highest percentage of 55 as the most important factor for selecting the type of CSP power plant. In the second position is security with 28.1 percent. This is mostly because security has a direct impact of over $10 \%$ on the whole cost of a project in Afghanistan. Table 2 is shown other specifications of four commercialized types of CSP technology. Considering four factors of MCDA and other factors from Table 2, the PTC with high commercialized maturity, most cost-effective aspect, and long durability is a suitable selection for a region like Afghanistan. 
Table-2.

Specifications of four commercialized types of CSP plants [36]

\begin{tabular}{|c|c|c|c|c|}
\hline & PTC & SPT & LFR & PDS \\
\hline Capacity range (MW) & $10-250$ & $10-100$ & $5-250$ & $0.01-1$ \\
\hline $\begin{array}{l}\text { Operating temperature range } \\
\left({ }^{\circ} \mathrm{C}\right)\end{array}$ & $150-400$ & $300-1200$ & $150-400$ & $300-1500$ \\
\hline Solar concentration ratio & $50-90$ & $600-1000$ & $35-170$ & $<3000$ \\
\hline $\begin{array}{l}\text { Solar to electricity efficiency } \\
(\%)\end{array}$ & $10-16$ & $10-22$ & $8-12$ & $16-29$ \\
\hline Relative cost & Low & High & Low & Very high \\
\hline \multirow[t]{2}{*}{ Power cycle } & Steam Rankine; & Steam Rankine; & Steam Rankine; & $\begin{array}{l}\text { Stirling Engine; Steam } \\
\text { Rankine; }\end{array}$ \\
\hline & Organic Rankine & Brayton cycle (gas turbine) & Organic Rankine & Brayton cycle (gas turbine) \\
\hline Commercial maturity & High & Medium & Medium & Low \\
\hline Outlook for improvements & limited & Very significant & significant & $\begin{array}{l}\text { High potential through } \\
\text { mass production }\end{array}$ \\
\hline \multirow[t]{3}{*}{ Advantages } & $\begin{array}{l}\text { Long term proved reliability } \\
\text { and durability: }\end{array}$ & High efficiency: & $\begin{array}{l}\text { Simple structure and easy } \\
\text { construction; }\end{array}$ & High efficiency: \\
\hline & Modular components; & $\begin{array}{l}\text { Compatible with Brayton cycle and } \\
\text { combined cycles burning oil or gas; }\end{array}$ & Modular units; & Modular units; \\
\hline & $\begin{array}{l}\text { Compatible with combined } \\
\text { cycles burning oil or gas; }\end{array}$ & Modular components; & $\begin{array}{l}\text { Compatible with combined } \\
\text { cycles burning oil or gas; }\end{array}$ & No need for water cooling \\
\hline \multirow[t]{2}{*}{ Disadvantages } & Relatively low efficiency; & $\begin{array}{l}\text { High maintenance and equipment } \\
\text { costs; }\end{array}$ & $\begin{array}{l}\text { Relatively low efficiency; limited } \\
\text { operational temperature }\end{array}$ & Low commercial maturity; \\
\hline & $\begin{array}{l}\text { Limited operational } \\
\text { temperature; } \\
\text { Complex structure; } \\
\text { Need water for cooling and } \\
\text { cleaning }\end{array}$ & Need water for cooling and cleaning & & $\begin{array}{l}\text { No thermal storage } \\
\text { available }\end{array}$ \\
\hline
\end{tabular}

\subsection{Simulation of a $3.5 \mathrm{MW}$ parabolic trough power plant via SAM software}

The System advisor model (SAM) software is a performance and financial designed to facilitate decision-making for people involved in the renewable energy industry. Based on the necessity of the Kang population a 3.5 MW PTC power plant is designed and simulated with the SAM 2020.11.29 version. Table 3 shows the result of this simulation. The cost of the simulated power plant used in the design process is taken from the average prices of CSP technology in a ten-year period, which is $7320 \$ / \mathrm{kW}$ [37]. Ten percent losses for transmission and irregular utilization of electricity are also considered. In addition, a factor of 1.1 is multiplied by the total cost of this project due to the precarious security situation of Afghanistan. The heat transfer fluid used in the receiver tubes of this PTC power plant is Hitec, which has a higher heat carrying capacity than liquid sodium.

Table-3.

Summary result of 3.5 MW PTC plant simulated in SAM.

\begin{tabular}{|ll|}
\hline Metric & Value \\
\hline Annual Net Electrical Energy Production & $10,064,959 \mathrm{kWh}-\mathrm{e}$ \\
\hline Annual Freeze Protection & $1,196,907 \mathrm{kWh}-\mathrm{e}$ \\
\hline Annual TES Freeze Protection & $1,156,126 \mathrm{kWh}-\mathrm{e}$ \\
Annual Field Freeze Protection & $40,781 \mathrm{kWh}-\mathrm{e}$ \\
Capacity factor & $33.8 \%$ \\
Power cycle gross electrical output & $13,079,871 \mathrm{kWh}-\mathrm{e}$ \\
First year kWh/kW & $2,965-$ \\
Gross-to-net conversion & $76.9 \%$ \\
Annual Water Usage & $2,434 \mathrm{~m}^{\wedge} 3$ \\
Levelized cost of energy & $30.57 \mathrm{c} / \mathrm{kWh}$ \\
\hline
\end{tabular}

Table 3 is the summary of design and simulation which shows that this project produces 10065 GWh of net electrical energy, with a capacity factor of $33.8 \%$ in the given 25 years. The LCOE for the PTC power plant is $30.57 \not / \mathrm{kWh}$ in Afghanistan. Compared to the LCOE of photovoltaic systems in Afghanistan with $9.17 \phi / \mathrm{kWh}$ it costs 3.3 times more. This price is even higher than the electricity generated from fossil fuels using.

$$
\text { Capacity Factor }=\frac{\text { Actual electrical energy output over given period of time }}{\text { Maximum possible electrical energy output over given period of time }}
$$


The graph in Figure 13 shows the rate of monthly generated electricity of the project for twelve months of a year. The lowest rate of energy production with 300-400 MW is during January and February, at the beginning of winter. The temperature fluctuation during the coldest days of winter in Kang is recorded to be -5 to $12{ }^{\circ} \mathrm{C}$. On the other hand, the highest rate of electricity generation is during the summer in May, June, and July with a temperature of $30-45^{\circ} \mathrm{C}$. Owing to the hot and dry weather of Nimruz province the minus temperature is only experienced for two months of winter, so it resulted in the production of an average of $840 \mathrm{MW}$ electrical energy over the year.

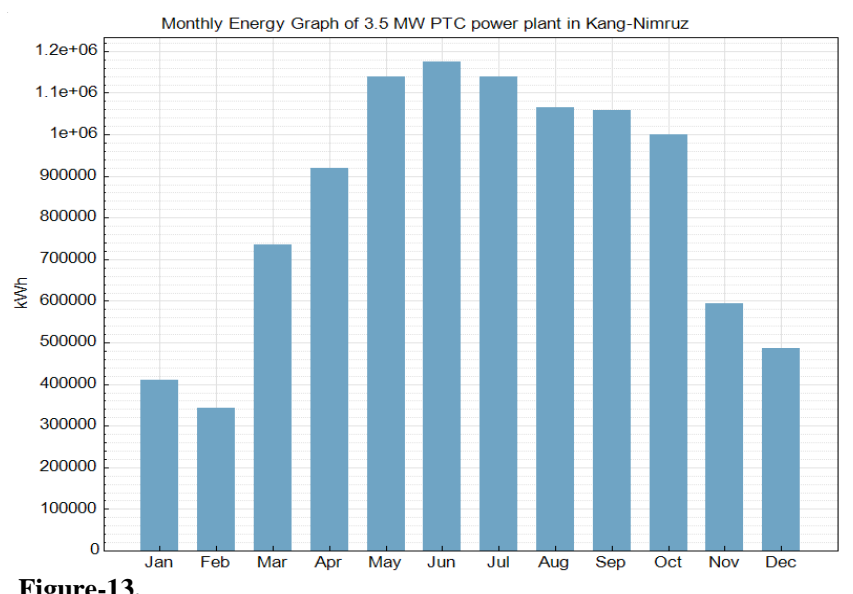

Figure-13.

Monthly generated electricity of 3.5 MW PTC power plant, simulated in the SAM.

\section{Conclusions}

Afghanistan is a mountainous country with difficult terrain, insecure situations, and dispersed populations, therefore, implementing large projects not only is difficult but also costs $10 \%$ more due to the lack of security. The national power grid and CSP technologies are both mega projects and security could be one of the reasons the electricity is not provided for rural areas of the country through these projects. On the other hand, electricity is generated through fossil fuel is not only expensive that rural people cannot pay for but also has adverse effects on the environment by producing $\mathrm{CO}_{2}$, thus, solar energy is the best replacement for these sources of energies. In the current study, 31 PV mini-grid projects implemented in the Kang district, Nimruz compared with fossil fuel electricity and CSP technology based on the Levelized cost of energy (LCOE). A $3.5 \mathrm{MW}$ concentrated solar power system in the form of PTC is simulated and analyzed in the system advisor model (SAM) software shows the CSP technology in Afghanistan is not as cost-effective as the PV technology is. All parts of Afghanistan have the potential of supplying electricity via thermal energy, in some provinces, the DNI potential is over $7 \mathrm{kWh} / \mathrm{m}^{2}$ including Ghor, Zabul, Paktia Ghazni, and some parts of Herat, Bamyan, and Wardak. Additionally, the land is enough available for whatever size of the project to be implemented in Afghanistan, the efficiency of land utilization for PV technology is over $22 \%$ higher per $\mathrm{kWh}$ rather than for CSP technology. On the other hand, operation, maintenance, and administration of PV projects are much easier due to its size and technical issues in Afghanistan. However, the PV analysis and study are all based on practical works with details, but the analysis of CSP technology is done through this study is a passing and superficial study that need to be more investigated based on the economic aspects, such as tax rate, inflation rate, and nominal construction interest rate.

\section{References}

[1] P. M. Murphy, S. Twaha, and I. S. Murphy, "Analysis of the cost of reliable electricity: A new method for analyzing grid connected solar, diesel and hybrid distributed electricity systems considering an unreliable electric grid, with examples in Uganda," Energy, vol. 66, pp. 523-534, 2014.

[2] W. Bank, "Unlocking the potential of agriculture for Afghanistan's growth. Retrieved from https://www.worldbank.org/en/country/afghanistan/publication/unlocking-potential-of-agriculture-for-afghanistan-growth," 2018.

[3] T. News, "Afghanistan annually pays $\$ 280 \mathrm{M}$ for imported power. Rerieved from https://tolonews.com/business/afghanistanannually-pays-280m-imported-power," 2020.

[4] World Bank Group, Afghanistan renewable energy development issues and options. Washington, DC: World Bank, 2018.

[5] M. A. Anwarzai and K. Nagasaka, "Utility-scale implementable potential of wind and solar energies for Afghanistan using GIS multi-criteria decision analysis," Renewable and Sustainable Energy Reviews, vol. 71, pp. 150-160, 2017. Available at: https://doi.org/10.1016/j.rser.2016.12.048.

[6] M. Cococcioni, E. D'Andrea, and B. Lazzerini, "24-hour-ahead forecasting of energy production in solar PV systems," presented at the 11th International Conference on Intelligent Systems Design and Applications. IEEE, 2011

[7] Ecoscore, "How to calculate the $\mathrm{CO} 2$ emission from the fuel consumption. Retrieved from https://ecoscore.be/en/info/ecoscore/co2," 2020.

[8] A. M. Ibrahimi, M. M. Sediqi, H. O. R. Howlader, M. S. S. Danish, S. Chakraborty, and T. Senjyu, "Generation expansion planning considering renewable energy integration and optimal unit commitment: A case study of Afghanistan," AIMS Energy, vol. 7, pp. 441-464, 2019. Available at: https://doi.org/10.3934/energy.2019.4.441.

[9] Globalsolaratlas, "Afghanistan. Retrieved from https://globalsolaratlas.info/download/afghanistan," 2019. 
[10] Solarpaces, "How CSP's thermal energy storage works. Retrieved from https://www.solarpaces.org/how-csp-thermal-energystorage-works," 2017.

[11] Scia.net, "Dewa concentrated solar power tower. Retrieved from https://www.scia.net/en/company/references/projects/dewaconcentrated-solar-power-tower," 2020.

[12] F. Rinaldi, M. Binotti, A. Giostri, and G. Manzolini, "Comparison of linear and point focus collectors in solar power plants," Energy Procedia, vol. 49, pp. 1491-1500, 2014. Available at: https://doi.org/10.1016/j.egypro.2014.03.158.

[13] J. P. Bijarniya, K. Sudhakar, and P. Baredar, "Concentrated solar power technology in India: A review," Renewable and Sustainable Energy Reviews, vol. 63, pp. 593-603, 2016. Available at: https://doi.org/10.1016/j.rser.2016.05.064.

[14] H. Liang, S. You, and H. Zhang, "Comparison of different heat transfer models for parabolic trough solar collectors," Applied Energy, vol. 148, pp. 105-114, 2015. Available at: https://doi.org/10.1016/j.apenergy.2015.03.059.

[15] W. Fuqiang, C. Ziming, T. Jianyu, Y. Yuan, S. Yong, and L. Linhua, "Progress in concentrated solar power technology with parabolic trough collector system: A comprehensive review," Renewable and Sustainable Energy Reviews, vol. 79, pp. 13141328, 2017. Available at: https://doi.org/10.1016/j.rser.2017.05.174.

[16] Y. Gao, Q. Zhang, R. Fan, X. Lin, and Y. Yu, "Effects of thermal mass and flow rate on forced-circulation solar hot-water system: comparison of water-in-glass and U-pipe evacuated-tube solar collectors," Solar Energy, vol. 98, pp. 290-301, 2013. Available at: https://doi.org/10.1016/j.solener.2013.10.014.

[17] Q. Mao, "Recent developments in geometrical configurations of thermal energy storage for concentrating solar power plant," Renewable and Sustainable Energy Reviews, vol. 59, pp. 320-327, 2016. Available at: https://doi.org/10.1016/j.rser.2015.12.355.

[18] B. Belgasim, Y. Aldali, M. J. Abdunnabi, G. Hashem, and K. Hossin, "The potential of concentrating solar power (CSP) for electricity generation in Libya," Renewable and Sustainable Energy Reviews, vol. 90, pp. 1-15, 2018. Available at: https://doi.org/10.1016/j.rser.2018.03.045.

[19] G. Kumaresan, P. Sudhakar, R. Santosh, and R. Velraj, "Experimental and numerical studies of thermal performance enhancement in the receiver part of solar parabolic trough collectors," Renewable and Sustainable Energy Reviews, vol. 77, pp. 1363-1374, 2017. Available at: https://doi.org/10.1016/j.rser.2017.01.171.

[20] Dlr.de, "Energy systems analysis. Retrieved from https://www.dlr.de/content/en/articles/energy/programme-topics/energysystems-analysis.html " n.d.

[21] S. Qazi, Standalone photovoltaic (PV) systems for disaster relief and remote areas: Elsevier, 2016.

[22] Y. Hu, Z. Xu, C. Zhou, J. Du, and Y. Yao, "Design and performance analysis of a multi-reflection heliostat field in solar power tower system," Renewable Energy, vol. 160, pp. 498-512, 2020. Available at: https://doi.org/10.1016/j.renene.2020.06.113.

[23] E. Bellos, "Progress in the design and the applications of linear Fresnel reflectors-A critical review," Thermal Science and Engineering Progress, vol. 10, pp. 112-137, 2019. Available at: https://doi.org/10.1016/j.tsep.2019.01.014.

[24] Fineartamerica, "Fine art America compact linear fresnel reflector canvas print. Retrieved from https://fineartamerica.com/featured/compact-linear-fresnel-reflector-us-department-of-energy.html," n.d.

[25] H. Yağli, "Examining the receiver heat loss, parametric optimization and exergy analysis of a solar power tower (SPT) system," Energy Sources, Part A: Recovery, Utilization, and Environmental Effects, vol. 42, pp. 2155-2180, 2020. Available at: https://doi.org/10.1080/15567036.2020.1748765.

[26] Pinterest, "The 580 MW noor ouarzazate solar power station. Retrieved from https://fi.pinterest.com/pin/714242822143557554/," n.d.

[27] Helioscsp, "No title power tower systems. Retrieved from http://helioscsp.com/how-concentrated-solar-power-works-towertrough-fresnel-or-dish/," n.d.

[28] H. Müller-Steinhagen and F. Trieb, "Concentrating solar power," A Review of the Technology. Ingenia Inform QR Acad Eng, vol. 18, pp. 43-50, 2004.

[29] H. Zhang, J. Baeyens, J. Degrève, and G. Cacères, "Concentrated solar power plants: Review and design methodology," Renewable and Sustainable Energy Reviews, vol. 22, pp. 466-481, $2013 . \quad$ Available at: https://doi.org/10.1016/j.rser.2013.01.032.

[30] T. Mancini, P. Heller, B. Butler, B. Osborn, W. Schiel, V. Goldberg, R. Buck, R. Diver, C. Andraka, and J. Moreno, "DishStirling systems: An overview of development and status," Journal of Solar Energy Engineering, vol. 125, pp. 135-151, 2003. Available at: https://doi.org/10.1115/1.1562634.

[31] M. Orosz and R. Dickes, Solar thermal powered organic rankine cycles. In: Organic Rankine Cycle (ORC) Power Systems: Elsevier, 2017.

[32] A. M. Ibrahimi, H. O. R. Howlader, M. S. S. Danish, R. Shigenobu, M. M. Sediqi, and T. Senjyu, "Optimal unit commitment with concentrated solar power and thermal energy storage in Afghanistan electrical system," International Journal of Emerging Electric Power Systems, vol. 20, 2019.

[33] K. Kaygusuz, "Prospect of concentrating solar power in Turkey: the sustainable future," Renewable and Sustainable Energy Reviews, vol. 15, pp. 808-814, 2011.

[34] N. K. Raja, M. S. Khalil, S. A. Masood, and M. Shaheen, "Design and manufacturing of parabolic trough solar collector system for a developing country Pakistan," Journal of American Science, vol. 7, 2011.

[35] Weatherspark, "Average weather in Zaranj. Retrieved from https://weatherspark.com/y/106064/Average-Weather-in-ZaranjAfghanistan-Year-Round," 2020.

[36] X. Xu, K. Vignarooban, B. Xu, K. Hsu, and A. M. Kannan, "Prospects and problems of concentrating solar power technologies for power generation in the desert regions," Renewable and Sustainable Energy Reviews, vol. 53, pp. 1106-1131, 2016. Available at: https://doi.org/10.1016/j.rser.2015.09.015.

[37] Statista, "Average installation cost for concentrated solar power (CSP) worldwide from 2010 to 2019 (in U.S. dollars per kilowatt). Retrieved from https://www.statista.com/statistics/799359/global-concentrated-solar-power-installation-cost-perkilowatt," 2020. 